\title{
High-time-resolution profiles of soluble ions in the last glacial period of a Dome Fuji (Antarctica) deep ice core
}

\author{
Yoshinori IIZUKA, ${ }^{1}$ Morimasa TAKATA, ${ }^{2}$ Takeo $\mathrm{HONDOH}^{2}{ }^{2}$ Yoshiyuki FUJI ${ }^{3}$ \\ ${ }^{1}$ Yuge National College of Maritime Technology, Ehime 794-2506, Japan \\ E-mail: iizuka@gen.yuge.ac.jp \\ ${ }^{2}$ Institute of Low Temperature Science, Hokkaido University, Sapporo 060-0819, Japan \\ ${ }^{3}$ National Institute of Polar Research, Kaga, Itabashi-ku, Tokyo 173-8515, Japan
}

\begin{abstract}
We measured the depth profiles of soluble ions in the Dome Fuji (Antarctica) ice core to search for possible paleoclimate indications of seasonal climate variations in the last glacial period. A $523 \mathrm{~mm}$ long core section between $\mathbf{5 8 7 . 6 5}$ and $588.18 \mathrm{~m}$ depth was selected for this pilot study, and the high-resolution chemical analysis was done on $2 \mathrm{~mm}$ thick samples. Our results indicate that anioncation trapping in ice affects the profiles of the soluble ions and $\left[\mathrm{Na}^{+}\right]$in the core may preserve its seasonal signal. Correlation coefficients and the equivalent balances of the soluble ions suggest the following selective coexistences: (1) $\left[\mathrm{Cl}^{-}\right]=\left[\mathrm{Na}^{+}\right]$, (2) $\left[\mathrm{NO}_{3}{ }^{-}\right]=1 / 2\left[\mathrm{Ca}^{2+}\right]+\left[\mathrm{K}^{+}\right]$, and (3) $\left[\mathrm{SO}_{4}{ }^{2-}\right]=$ $1 / 2\left[\mathrm{Ca}^{2+}\right]+\left[\mathrm{H}^{+}\right]+\left[\mathrm{Mg}^{2+}\right]$. These coexistences are probably due to (1) a sea-salt source of $\mathrm{Na}^{+}$and $\mathrm{Cl}^{-}$, (2) reaction of $\mathrm{NO}_{3}{ }^{-}$with dust for $\mathrm{Ca}^{2+}$ and $\mathrm{NO}_{3}{ }^{-}$, and (3) anion-cation trapping in ice for $\mathrm{SO}_{4}{ }^{2-}$ and $\mathrm{Ca}^{2+}\left(\mathrm{Mg}^{2+}\right)$, respectively.
\end{abstract}

\section{INTRODUCTION}

Ice-core research is widely conducted to reconstruct regional and global paleoclimates. Because the inland regions on polar ice sheets generally have low snow-accumulation rates, ice cores drilled from the inland region of polar ice sheets are particularly important for reconstruction of longterm paleoclimates up to several hundred thousand years ago (Watanabe and others, 2003a). The time-scale of several hundred thousand years includes several glacial periods. On the other hand, it is often difficult to determine short-term climatic fluctuations because annual layers are generally thin. Even if the information is preserved and highly compressed in some small amount of samples, analysis requires a sufficient volume, which limits the minimum period of time that can be recovered from the ice core. This limits the minimum time interval that can be resolved for high-time-resolution analysis. Furthermore, post-depositional processes in ice sheets, such as molecular diffusion in ice, can easily obscure the depth profiles of paleoclimate signals, such as the isotopes of $\mathrm{H}_{2} \mathrm{O}$ and chemical compositions, in places where snow accumulates slowly (e.g. Barnes and others, 2003).

Researchers are often interested in annual or seasonalscale variations in ice cores (e.g. Legrand and Mayewski, 1997; Curran and others, 1998) for reconstruction of detailed climate and environment changes and for establishment of precise core dating. An ice core from the inland region in Greenland had seasonal variations in chemical composition during the Holocene (e.g. Steffensen, 1988; Whitlow and others, 1992) but not during the last glacial period. This is due to the thinning of annual layers with depth, long-term molecular diffusion in ice and lower accumulation rates during the glacial than during the Holocene. To detect seasonal variations during the last glacial period, we need to quantitatively determine how post-depositional processes such as molecular diffusion in ice affect the core properties. Then we will understand whether or not we can count annual layers of signals in the glacial period.
The Japanese Antarctic Research Expedition (JARE) conducted a deep ice coring at Dome Fuji $\left(77^{\circ} 19^{\prime} \mathrm{S}\right.$, $39^{\circ} 40^{\prime} \mathrm{E} ; 3810 \mathrm{~m}$ a.s.l.) from 1995 to 1996 . The project team recovered ice down to $2503 \mathrm{~m}$, which contains climatic data back to $320 \mathrm{kyr}$ (e.g. Watanabe and others, 1999, 2003a, b; Fujii and others, 2002). The present annual accumulation rate at Dome Fuji is about $30 \mathrm{~mm}$ w.e. $\mathrm{a}^{-1}$ (Kameda and others, 1997), and the annual thickness of Dome Fuji ice core is estimated to be about $15-20 \mathrm{~mm}$ for the Last Glacial Maximum (Watanabe and others, 2003b). Watanabe and others (2003c) showed that some ion concentrations in the surface snow at Dome Fuji have seasonal fluctuations. For example, concentrations of $\mathrm{Na}^{+}$ and $\mathrm{Cl}^{-}$in surface snow increased in spring. The concentration of $\mathrm{SO}_{4}{ }^{2-}$ attained maximum value in spring and late autumn, then decreased in late summer and winter. Also, $\mathrm{NO}_{3}{ }^{-}$had peak values in early summer and late winter, and $\mathrm{Cl}^{-} / \mathrm{Na}^{+}$increased in summer.

Using radar echo sounding, Fujita and others (2002) found that the inner structure of the ice sheet below Dome Fuji station has horizontal layering with no stratigraphic disturbances. This observation leads us to assume that paleoclimate signals are preserved as horizontal layers with no stratigraphic disturbances in deep ice of the Dome Fuji region, even though the annual layer is thinner for the deep ice than it is at the surface. In this paper, we present highresolution depth profiles of soluble ions from the last glacial period in the Dome Fuji ice core, discuss chemical reaction through post-deposition processes and search for possible seasonal variations.

\section{SAMPLING SITE AND ANALYTICAL PROCEDURE}

As a pilot study, we selected a $523 \mathrm{~mm}$ long ice core from depths of $587.65-588.18 \mathrm{~m}$. These depths contain ice that was deposited 25-26 kyr вP (Watanabe and others, 2003b). This section corresponds to the coldest period of the last glacial. A slab-shaped, $40 \mathrm{~mm}$ thick sample was cut from the ice core along the core axis. Then we sliced $3 \mathrm{~mm}$ off 
the outside of the ice core in a cold clean room using a pre-cleaned ceramic knife to decontaminate the surface. The cleaned ice core was sliced in the clean room with the ceramic knife every $2 \mathrm{~mm}$ of depth. Each sliced fraction was sealed in a Whirl-Pack in the clean room. In this way, we obtained 240 samples from the $500 \mathrm{~mm}$ long core (the bottom $23 \mathrm{~mm}$ were used to attach the ice to the vise). The annual accumulation rate for the period corresponding to this sample is estimated to be $15-16 \mathrm{~mm}$ (Watanabe and others, 2003b); thus, the $2 \mathrm{~mm}$ thick sampling allows us to detect seasonal variations.

After melting an ice sample in a Whirl-Pack, we analyzed the liquid for eight major soluble ions $\left(\mathrm{Cl}^{-}, \mathrm{NO}_{3}{ }^{-}, \mathrm{SO}_{4}{ }^{2-}, \mathrm{F}^{-}\right.$, $\mathrm{Na}^{+}, \mathrm{K}^{+}, \mathrm{Mg}^{2+}$ and $\mathrm{Ca}^{2+}$ ) with an ion chromatograph (Dionex 500). The major soluble ions were analyzed after the sample was filtered with a pore size of $0.45 \mu \mathrm{m}$. The concentration of soluble ions was measured with an estimated error of $<3 \%$. As a reference, we analyzed ultrapure water through the same techniques and found no peaks on the chromatograph. This test indicates that our technique does not introduce detectable contamination.

\section{RESULTS}

Figure 1 shows depth profiles of soluble ions from 587.65 to $588.18 \mathrm{~m}$. The acidity, $\mathrm{H}^{+}$, is assumed to equal

$$
\begin{aligned}
{\left[\mathrm{H}^{+}\right]=} & {\left[\mathrm{Cl}^{-}\right]+\left[\mathrm{NO}_{3}{ }^{-}\right]+\left[\mathrm{SO}_{4}{ }^{2-}\right]+\left[\mathrm{F}^{-}\right] } \\
& -\left(\left[\mathrm{Na}^{+}\right]+\left[\mathrm{K}^{+}\right]+\left[\mathrm{Mg}^{2+}\right]+\left[\mathrm{Ca}^{2+}\right]\right) \quad\left(\mu \mathrm{eqL}{ }^{-1}\right) .
\end{aligned}
$$

The primary anion is $\mathrm{Cl}^{-}$with an average concentration of $5.85 \mu \mathrm{mol} \mathrm{L}^{-1}$, the second is $\mathrm{SO}_{4}{ }^{2-}$ with $3.18 \mu \mathrm{mol} \mathrm{L}^{-1}$ and the third is $\mathrm{NO}_{3}{ }^{-}$with $2.06 \mu \mathrm{mol} \mathrm{L}^{-1}$. The primary cation is $\mathrm{Na}^{+}$with an average of $5.46 \mu \mathrm{mol} \mathrm{L}^{-1}$, the second is $\mathrm{H}^{+}$with $2.64 \mu \mathrm{mol} \mathrm{L}^{-1}$ and the third is $\mathrm{Ca}^{2+}$ with $2.03 \mu \mathrm{mol} \mathrm{L}^{-1}$. All anions and cations show synchronous fluctuations except in the depth range $588.03-588.09 \mathrm{~m}$ shown as gray column in Figure 1, where higher $\mathrm{SO}_{4}{ }^{2-}$ and $\mathrm{H}^{+}$levels occurred simultaneously with depressed anions. This event may be due to fallout of volcanic $\mathrm{H}_{2} \mathrm{SO}_{4}$. The fluctuation periods range from several millimeters to several centimeters.

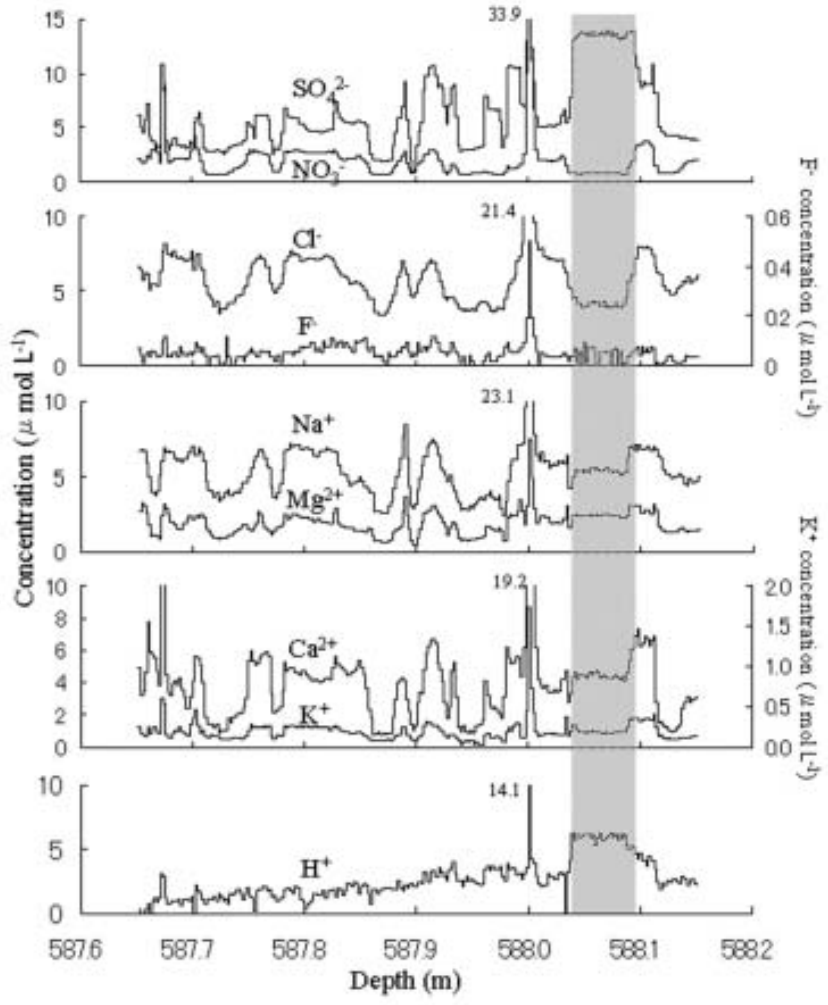

Fig. 1. Vertical distributions of eight ion species from 587.65 to $588.18 \mathrm{~m}$ depth in the Dome Fuji ice core. Resolution is $2 \mathrm{~mm}$. The gray shaded column shows the depth from 587.03 to $588.09 \mathrm{~m}$ having non-synchronous fluctuations of cations and anions.

\section{DISCUSSION}

\section{Coexistence of specific anions and cations}

Table 1 shows correlation coefficients between ion pairs for the entire section of this sample. We did not use the ion concentrations near $588.00 \mathrm{~m}$ in the statistical analyses because this depth has extremely high ion concentrations and the high concentrations would produce apparently high

Table 1. Correlation coefficient matrix for ion species and the sums of their equivalents for ice from 587.65 to $588.18 \mathrm{~m}$ in the Dome Fuji ice core. Italic values indicate correlation coefficients exceeding 0.6. The bold value shows the correlation coefficient between $\mathrm{Ca}^{2+}$ and

\begin{tabular}{|c|c|c|c|c|c|c|c|c|c|}
\hline & $\mathrm{F}^{-}$ & $\mathrm{Cl}^{-}$ & $\mathrm{NO}_{3}{ }^{-}$ & $\mathrm{SO}_{4}^{2-}$ & $\mathrm{Na}^{+}$ & $\mathrm{K}^{+}$ & $\mathrm{Mg}^{2+}$ & $\mathrm{Ca}^{2+}$ & $\mathrm{H}^{+}$ \\
\hline $\mathrm{F}^{-}$ & 1.00 & & & & & & & & \\
\hline $\mathrm{Cl}^{-}$ & 0.41 & 1.00 & & & & & & & \\
\hline $\mathrm{NO}_{3}^{-}$ & 0.51 & 0.73 & 1.00 & & & & & & \\
\hline $\mathrm{SO}_{4}^{2-}$ & 0.21 & -0.02 & 0.02 & 1.00 & & & & & \\
\hline $\mathrm{K}^{+}$ & 0.51 & 0.60 & 0.75 & 0.51 & 0.73 & 1.00 & & & \\
\hline $\mathrm{Mg}^{2+}$ & 0.36 & 0.58 & 0.42 & 0.68 & 0.86 & 0.72 & 1.00 & & \\
\hline $\mathrm{Ca}^{2+}$ & 0.58 & 0.59 & 0.78 & 0.56 & 0.65 & 0.88 & 0.68 & 1.00 & \\
\hline $\mathrm{H}^{+}$ & -0.04 & -0.30 & -0.20 & 0.85 & 0.05 & 0.17 & 0.32 & 0.23 & 1.00 \\
\hline $\mathrm{Mg}^{2+}+\mathrm{H}^{+}$ & 0.10 & -0.04 & -0.02 & 0.95 & 0.35 & 0.41 & 0.63 & 0.43 & 0.94 \\
\hline $\mathrm{K}^{+}+\mathrm{Ca}^{2+}$ & 0.58 & 0.59 & 0.79 & 0.56 & 0.65 & 0.89 & 0.69 & 1.00 & 0.23 \\
\hline $\mathrm{Mg}^{2+}+\mathrm{H}^{+}+1 / 2 \mathrm{Ca}^{2+}$ & 0.31 & 0.20 & 0.30 & 0.94 & 0.52 & 0.66 & 0.75 & 0.73 & 0.81 \\
\hline $\mathrm{NO}_{3}{ }^{-}+\mathrm{SO}_{4}{ }^{2-}$ & 0.35 & 0.21 & 0.33 & 0.95 & 0.58 & 0.71 & 0.78 & 0.77 & 0.74 \\
\hline $\mathrm{Cl}^{-} / \mathrm{Na}^{+}$ & -0.07 & 0.10 & 0.16 & -0.77 & -0.46 & -0.30 & -0.60 & -0.23 & -0.55 \\
\hline
\end{tabular}
$\mathrm{NO}_{3}{ }^{-}+\mathrm{SO}_{4}{ }^{2-}$ 

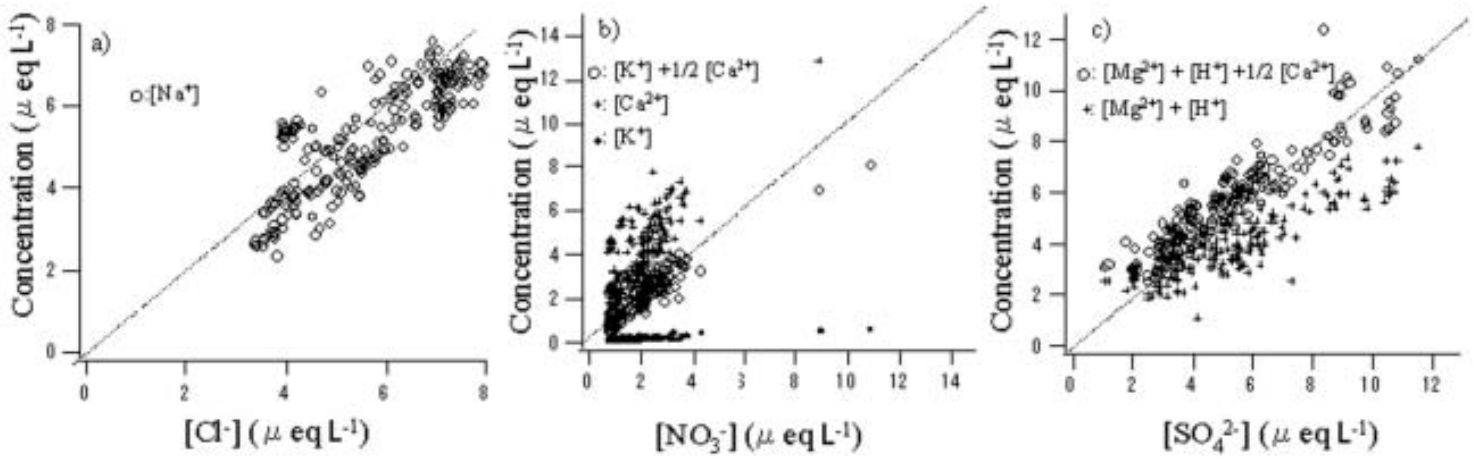

Fig. 2. Comparisons of anions and cations that have correlation coefficients exceeding 0.6. Dotted lines show equivalence between the anion and cation.

coefficients. We focus on anion and cation pairs having correlation coefficients exceeding 0.6. These include (1) $\mathrm{Cl}^{-}$ with $\mathrm{Na}^{+}(r=0.83)$, (2) $\mathrm{NO}_{3}^{-}$with $\mathrm{K}^{+}(0.75)$ and $\mathrm{Ca}^{2+}$ (0.78), and (3) $\mathrm{SO}_{4}{ }^{2-}$ with $\mathrm{Mg}^{2+}(0.68)$ and $\mathrm{H}^{+}(0.85)$.

Figure 2 shows quantitative comparisons of anion and cation pairs with correlation coefficient higher than 0.6. The $\mathrm{Cl}^{-}$concentration roughly equals the $\mathrm{Na}^{+}$concentration (Fig. 2a). The $\mathrm{NO}_{3}{ }^{-}$concentration is lower than the sum of the $\mathrm{K}^{+}$and $\mathrm{Ca}^{2+}$ concentrations but much higher than the $\mathrm{K}^{+}$ concentration (Fig. 2b). Therefore, $\mathrm{Ca}^{2+}$ contributes most of the cation excess. Assuming $1 / 2\left[\mathrm{Ca}^{2+}\right]$ and $\left[\mathrm{K}^{+}\right]$for the $\left[\mathrm{NO}_{3}{ }^{-}\right]$pairs, we obtained good quantitative balance between this cation and anion pair. The $\mathrm{SO}_{4}{ }^{2-}$ concentration generally exceeds the sum of the $\mathrm{Mg}^{2+}$ and $\mathrm{H}^{+}$concentrations (Fig. 2c). Assuming the cation deficit is due to the rest of $\left[\mathrm{Ca}^{2+}\right]$, namely $1 / 2\left[\mathrm{Ca}^{2+}\right]$, a very high correlation coefficient and good quantitative balance are obtained between this anion and cation pair. As a result, we obtain the following equations:

$$
\begin{aligned}
{\left[\mathrm{Cl}^{-}\right] } & =\left[\mathrm{Na}^{+}\right] \quad(r=0.83) \\
{\left[\mathrm{NO}_{3}{ }^{-}\right] } & =\left[\mathrm{K}^{+}\right]+1 / 2\left[\mathrm{Ca}^{2+}\right] \quad(r=0.79) \\
{\left[\mathrm{SO}_{4}{ }^{2-}\right] } & =\left[\mathrm{Mg}^{2+}\right]+\left[\mathrm{H}^{+}\right]+1 / 2\left[\mathrm{Ca}^{2+}\right] \quad(r=0.94)
\end{aligned}
$$

The $\mathrm{Ca}^{2+}$ concentration correlates well with $\mathrm{NO}_{3}{ }^{-}+\mathrm{SO}_{4}{ }^{2-}$ $(r=0.77)$. This indicates that $\mathrm{Ca}^{2+}$ coexists with both $\mathrm{NO}_{3}{ }^{-}$ and $\mathrm{SO}_{4}{ }^{2-}$, which supports the above-mentioned assumptions. We show the proposed cation pairs for $\mathrm{NO}_{3}{ }^{-}$and $\mathrm{SO}_{4}{ }^{2-}$ in Figure $2 \mathrm{~b}$ and $\mathrm{c}$, respectively.

Röthlisberger and others (2003) showed that $\mathrm{Na}^{+}$and $\mathrm{Cl}^{-}$ in the Dome $\mathrm{C}$ ice core coexisted as a sea salt during the last glacial period. The present study suggests that this also holds for $\mathrm{Na}^{+}$and $\mathrm{Cl}^{-}$in the Dome Fuji ice core. Legrand and others (1999) and Röthlisberger and others (2002) found a high correlation between $\mathrm{NO}_{3}{ }^{-}$and $\mathrm{Ca}^{2+}$ in Vostok and Dome $\mathrm{C}$ ice cores respectively during the last glacial period. The cause was thought to be the reaction of $\mathrm{NO}_{3}{ }^{-}$with dust under the low temperatures that will reduce the $\mathrm{NO}_{3}{ }^{-}$ volatilization in snow. Our results show that the Dome Fuji ice core also has a high correlation between $\mathrm{NO}_{3}{ }^{-}$and $\mathrm{Ca}^{2+}$ for the ice from the last glacial period.

Except for the possibility that some $\mathrm{SO}_{4}{ }^{2-}$ came from $\mathrm{H}_{2} \mathrm{SO}_{4}$, the $\mathrm{SO}_{4}{ }^{2-}$ in this ice-core sample probably exists as $\mathrm{CaSO}_{4}$ and $\mathrm{MgSO}_{4}$. Sources of $\mathrm{SO}_{4}{ }^{2-}$ and $\mathrm{Ca}^{2+}\left(\mathrm{Mg}^{2+}\right)$ are probably different; the major amount of $\mathrm{SO}_{4}{ }^{2-}$ originated from the production of marine bioorganic (Ayers and others,
1991) and/or from the stratosphere, whereas $\mathrm{Ca}^{2+}$ and $\mathrm{Mg}^{2+}$ came from dust and/or sea salt (Legrand and Mayewski, 1997). Cragin and others (1993) showed that a non-volatile acid such as $\mathrm{SO}_{4}{ }^{2-}$ is likely to remain in the snow even when the snow evaporates. This $\mathrm{SO}_{4}{ }^{2-}$ behavior suggests that the coexistences such as $\mathrm{MgSO}_{4}$ and $\mathrm{CaSO}_{4}$ are not due to the reaction of dust in the snow with volatile anions such as the coexistence of $\mathrm{Ca}\left(\mathrm{NO}_{3}\right)_{2}$.

Barnes and others (2003) estimated the diffusion coefficients of $\mathrm{Cl}^{-}$and $\mathrm{SO}_{4}{ }^{2-}$ in a Dome $\mathrm{C}$ ice core to be about $10^{-14}$ and $10^{-16} \mathrm{~m}^{2} \mathrm{~s}^{-1}$, respectively, but the diffusion of $\mathrm{Na}^{+}$ was not detected. The diffusion coefficients of $\mathrm{Cl}^{-}$and $\mathrm{SO}_{4}{ }^{2-}$ are large enough to smooth out peaks separated by less than about $1 \mathrm{~cm}$ over the time period of 25-26 kyr. However, the $\mathrm{Cl}^{-}$and $\mathrm{SO}_{4}{ }^{2-}$ profiles in the Dome Fuji ice core have millimeter to centimeter peak separations. Livingston and George (2002) suggested that the diffusion of $\mathrm{H}_{2} \mathrm{O}$ and/or ion species in an ice is restrained when an ion pair of anion and cation forms, a process they call anion-cation trapping. Because the entire section of the ice-core sample actually has several anion and cation pairs (Table 1), and anioncation trapping probably occurred, the ion fluctuations still remain on millimeter to centimeter scales. Recent SEM analysis detected $\mathrm{NaCl}$ and $\mathrm{MgSO}_{4}$ in triple junctions in polar ice cores (Barnes and others, 2002; Cullen and Baker, 2002). Our results show that the Dome Fuji ice core has similar coexistences, and that specific coexistences of the above species help to clarify the general characteristics of ion behavior.

\section{Seasonal fluctuations of the depth profiles of ions species}

The concentrations of $\mathrm{Na}^{+}, \mathrm{Cl}^{-}, \mathrm{SO}_{4}{ }^{2-}$ and $\mathrm{NO}_{3}{ }^{-}$in surface snow at Dome Fuji show seasonal variations (Watanabe and others, 2003c). Both $\mathrm{SO}_{4}{ }^{2-}$ and $\mathrm{Na}^{+}$in surface snow have maxima in spring, and $\mathrm{SO}_{4}{ }^{2-}$ also has maxima in autumn. Near $588 \mathrm{~m}$ depth, seasonal variations of $\mathrm{Cl}^{-}$and $\mathrm{NO}_{3}{ }^{-}$ probably disappeared due to their volatilization in snow. Furthermore, the depth range 588.03-588.09 $\mathrm{m}$ shown as gray column in Figures 1 and 3 has asynchronous fluctuations of higher $\mathrm{SO}_{4}{ }^{2-}$ and $\mathrm{H}^{+}$levels compared to other ions. Therefore, we consider whether or not a $380 \mathrm{~mm}$ length of the ice core from 587.65 to $588.03 \mathrm{~m}$ has seasonal fluctuations in the $\mathrm{Na}^{+}$and $\mathrm{SO}_{4}{ }^{2-}$ profiles.

The $\mathrm{Na}^{+}$profile has millimeter- to centimeter-scale fluctuations over the $380 \mathrm{~mm}$ length of the ice core (Fig. 3). $\mathrm{Na}^{+}$concentration in the $380 \mathrm{~mm}$ length is an 
average of $5.46 \mu \mathrm{mol} \mathrm{L}^{-1}$, with an estimated error of $<3 \%$. Because the $3 \%$ is equal to $0.16 \mu \mathrm{mol} \mathrm{L}^{-1}$ for $\mathrm{Na}^{+}$, we counted $\mathrm{Na}^{+}$peaks in the $380 \mathrm{~mm}$ length that were at least $0.16 \mu \mathrm{mol} \mathrm{L}^{-1}$ larger than those in neighbor minimal concentrations. The $380 \mathrm{~mm}$ length has $24 \mathrm{Na}^{+}$peaks as the arrows shown in Figure 3. The average width between two peaks in the $380 \mathrm{~mm}$ length is $15.8 \mathrm{~mm}$, which coincides with the annual accumulation thickness of 15$16 \mathrm{~mm}$ in the entire section of the ice-core samples. This coincidence suggests that the $\mathrm{Na}^{+}$concentration may retain its seasonal signal.

The widths between two peaks vary widely. The standard deviation of the widths is $8.9 \mathrm{~mm}$. Observation of snow accumulation using 36 stakes at Dome Fuji in 1995 (Azuma and others, 1997), 1996 (Fujita and others, 1998) and 1997 (Motoyama and others, 1999) showed the average values and standard deviations as $88 \pm 36 \mathrm{~mm}$ in snow for 1995, $95 \pm 43 \mathrm{~mm}$ for 1996 , and $69 \pm 67 \mathrm{~mm}$ for 1997, respectively. These standard deviations correspond to $6.3,7.5$ and $15.3 \mathrm{~mm}$ respectively for the same average value of $15.8 \mathrm{~mm}$ as average width between two peaks in the $380 \mathrm{~mm}$ length core. The $8.9 \mathrm{~mm}$ standard deviation of the widths in the $380 \mathrm{~mm}$ length core is well in harmony with these standard deviations of snow accumulation rate in surface snow at Dome Fuji during 1995-97. This harmony suggests that the $\mathrm{Na}^{+}$concentration may retain its seasonal signal.

The $\mathrm{SO}_{4}{ }^{2-}$ profile has millimeter- to centimeter-scale fluctuations over the $380 \mathrm{~mm}$ length of the ice core (Fig. 3). The $380 \mathrm{~mm}$ length has $17 \mathrm{SO}_{4}{ }^{2-}$ peaks, shown by arrows in Figure 3, by counting in the same manner as for $\mathrm{Na}^{+}$peaks. The average width between two peaks in the $380 \mathrm{~mm}$ length is $22.2 \mathrm{~mm}$, which does not coincide with the annual accumulation thickness. The shortage of $\mathrm{SO}_{4}{ }^{2-}$ peaks may be due to the diffusion. This is consistent with the analysis on a Dome C ice core by Barnes and others (2003) reporting that $\mathrm{Na}^{+}$does not diffuse. These results suggest that the $\mathrm{Na}^{+}$ concentration in the Dome Fuji ice core may retain its seasonal signal.

\section{CONCLUDING REMARKS}

We examined anions and cations in an ice-core sample from 587.65 to $588.18 \mathrm{~m}$ depth of the Dome Fuji ice core and found the following. $\mathrm{Cl}^{-}$and $\mathrm{Na}^{+}$coexisted with a correlation coefficient of 0.83 , suggesting that they originate as sea salt and deposit as precipitation on the ice sheet. $\mathrm{Ca}^{2+}$ and $\mathrm{NO}_{3}{ }^{-}$coexisted, likely due to reactions of $\mathrm{NO}_{3}{ }^{-}$with dust. $\mathrm{SO}_{4}{ }^{2-}$ and $\mathrm{Ca}^{2+}\left(\mathrm{Mg}^{2+}\right)$ coexisted, probably due to anioncation trapping in snow or ice. Finally, $\mathrm{Na}^{+}$in the ice core may retain seasonal signals because $\mathrm{Na}^{+}$has negligible diffusion in ice.

\section{ACKNOWLEDGEMENTS}

We thank the Dome Fuji drilling team and all the participants in the JARE Dome Fuji traverse. We are grateful to S. Fujita and M. Igarashi for providing useful comments. We are also greatly indebted to K. Kreutz, an anonymous referee and the scientific editor $\mathrm{V}$. Maggi for valuable comments. This study was supported by Grants-in-Aid for Creative Scientific Research, grant No. 14GS0202, for Scientific Research (S), grant No. 15101001, and for Scientific Research (B), grant No. 16710012.

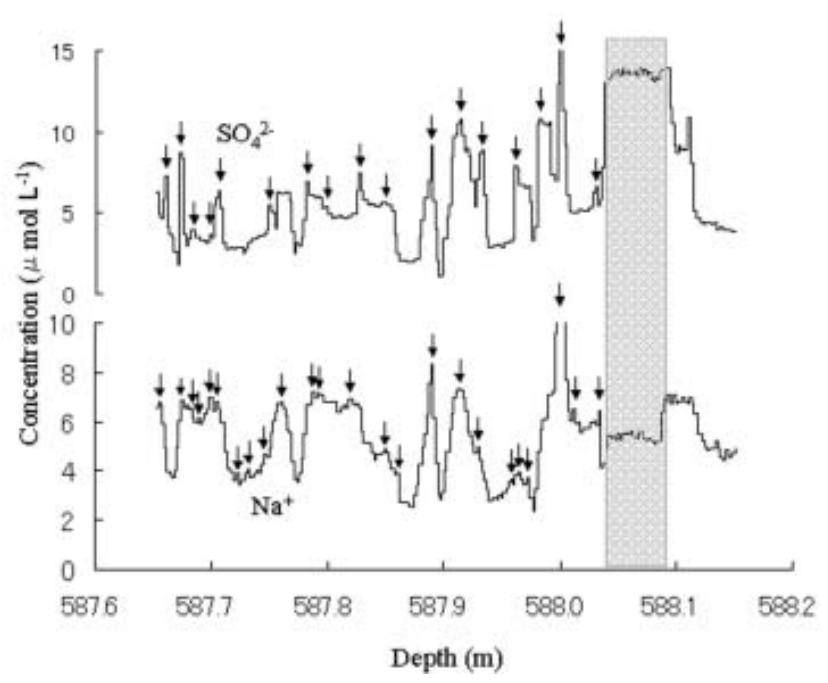

Fig. 3. Vertical distributions of $\mathrm{SO}_{4}{ }^{2-}$ and $\mathrm{Na}^{+}$of the same ice-core sample as Figure 1. Arrows mark $\mathrm{Na}^{+}$and $\mathrm{SO}_{4}{ }^{2-}$ peaks.

\section{REFERENCES}

Ayers, G. P., J.P. Ivey and R. W. Gillet. 1991. Coherence between seasonal cycles of dimethyl sulphide, methanesulphonate and sulphate in marine air. Nature, 349(6308), 404-406.

Azuma, N. and 6 others. 1997. Glaciological data collected by the 36th Japanese Antarctic Research Expedition during 1995-1996. JARE Data Rep. 223.

Barnes, P. R. F., R. Mulvaney, K. Robinson and E. W. Wolff. 2002. Observations of polar ice from the Holocene and the glacial period using the scanning electron microscope. Ann. Glaciol., 35, 559-566.

Barnes, P. R. F., E. W. Wolff, H. M. Mader, R. Udisti, E. Castellano and R. Röthlisberger. 2003. Evolution of chemical peak shapes in the Dome C, Antarctica, ice core. J. Geophys. Res., 108(D3), 4126. (10.1029/2002JD002538.)

Cragin, J. H., A. D. Hewitt and S. C. Colbeck. 1993. Elution of ions from melting snow: chromatographic versus metamorphic mechanisms. CRREL Rep. 93-8, 113.

Cullen, D. and I. Baker. 2002. Observation of sulfate crystallites in Vostok accretion ice. Materials Characterization, 48(4), 263-269.

Curran, M., T. D. van Ommen and V. Morgan. 1998. Seasonal characteristics of the major ions in the high-accumulation Dome Summit South ice core, Law Dome, Antarctica. Ann. Glaciol., 29, 385-390.

Fujii, Y. and 25 others. 2002. Deep ice core drilling to $2503 \mathrm{~m}$ depth at Dome Fuji, Antarctica. Nat. Inst. Polar Res. Mem., Ser. Special Issue 56, 103-116. (Ice Drilling Technology 2000.)

Fujita, S., K. Kawada and Y. Fujii. 1998. Glaciological data collected by the 37th Japanese Antarctic Research Expedition during 1996-1997. JARE Data Rep. 234. (Glaciology 27.)

Fujita, S., H. Maeno, T. Furukawa and K. Matsuoka. 2002. Scattering of VHF radio waves from within the top $700 \mathrm{~m}$ of the Antarctic ice sheet and its relation to the depositional environment: a case-study along the Syowa-Mizuho-Dome Fuji traverse. Ann. Glaciol., 34, 157-164.

Kameda, T., N. Azuma, T. Furukawa, Y. Ageta and S. Takahashi. 1997. Surface mass balance, sublimation and snow temperatures at Dome Fuji Station, Antarctica, in 1995. Proc. NIPR Symp. Polar Meteorol. Glaciol., 11, 24-34.

Legrand, M. and P. Mayewski. 1997. Glaciochemistry of polar ice cores: a review. Rev. Geophys., 35(3), 219-243.

Legrand, M., E. Wolff and D. Wagenbach. 1999. Antarctic aerosol and snowfall chemistry: implications for deep Antarctic ice-core chemistry. Ann. Glaciol., 29, 66-72. 
Livingston, F. E. and S. M. George. 2002. Effect of sodium on $\mathrm{HCl}$ hydrate diffusion in ice: evidence for anion-cation trapping. J. Phys. Chem., 106A, 5114-5119.

Motoyama, H., Y. Kawamura, M. Kanao, N. Hirasawa, S. Kaneto and T. Yamanouchi. 1999. Glaciological data collected by the 38th Japanese Antarctic Research Expedition during 1997-1998. JARE Data Rep. 239. (Glaciology 28.)

Röthlisberger, R. and 10 others. 2002. Nitrate in Greenland and Antarctic ice cores: a detailed description of post-depositional processes. Ann. Glaciol., 35, 209-216.

Röthlisberger, R. and 8 others. 2003. Limited dechlorination of sea salt aerosols during the last glacial period: evidence from the EPICA Dome C ice core. J. Geophys. Res., 108, 4526. (10.1029/2003JD003604.)

Steffensen, J. P. 1988. Analysis of the seasonal variation in dust, $\mathrm{Cl}^{-}$, $\mathrm{NO}_{3}{ }^{-}$, and $\mathrm{SO}_{4}{ }^{2-}$ in two central Greenland firn cores. Ann. Glaciol., 10, 171-177.
Watanabe, O., K. Kamiyama, H. Motoyama, Y. Fujii, H. Shoji and K. Satow. 1999. The palaeoclimate record in the ice core from Dome Fuji station, Antarctica. Ann. Glaciol., 29, 176-178.

Watanabe, O. and 6 others. 2003a. Dating of the Dome Fuji, Antarctica deep ice core. Nat. Inst. Polar Res. Mem., Ser. Special Issue 57, 25-37.

Watanabe, O. and 10 others. 2003b. General tendencies of stable isotopes and major chemical constituents of the Dome Fuji deep ice core. Nat. Inst. Polar Res. Mem., Ser. Special Issue 57, 1-24.

Watanabe, O., J. Jouzel, S. Johnsen, F. Parrenin, F. Shoji and N. Yoshida. 2003c. Homogeneous climate variability across East Antarctica over the past three glacial cycles. Nature, 422(6931), 509-512.

Whitlow, S., P. A. Mayewski and J. E. Dibb. 1992. A comparison of major chemical species seasonal concentration and accumulation at the South Pole and Summit, Greenland. Atmos. Environ., 26A(11), 2045-2054. 